\title{
UTILIZAÇÃO DE INTELIGÊNCIA ARTIFICIAL (REDES NEURAIS ARTIFICIAIS) NO GERENCIAMENTO DE REPRODUTORAS PESADAS*
}

\author{
ADRIANO DA SILVA GUAHYBA \\ Carlos Tadeu Pippi Salle (Orientador - UFRGS) \\ Vera Beatriz Wald (Co-Orientadora - UFRGS)
}

Banca Examinadora:

Alberto Back MERCOLAB

Antônio Mario Penz Júnior UFRGS

Ari Bernardes da Silva UFRGS

Uma atividade com a magnitude da avicultura, que usa equipamentos de última geração e serviços atualizados, é levada, na maioria dos casos, a tomar decisões que envolvem todos aspectos de produção, apoiada em critérios subjetivos. A presente tese objetivou estudar a utilização das redes neurais artificiais na estimação dos parâmetros de desempenho de matrizes pesadas, pertencentes a uma integração avícola sul-brasileira. Foram utilizados os registros de 11 lotes em recria, do período compreendido entre 09/11/97 a 10/01/99 e de 21 lotes em produção, do período compreendido entre 26/04/98 a 19/12/99, para a análise por redes neurais artificiais. Os dados utilizados corresponderam a 273 linhas de registros semanais, do período de recria e 689 linhas de registros semanais, do período de produção. Os modelos de redes neurais foram comparados e selecionados como melhores, baseados no coeficiente de determinação múltipla $\left(\mathrm{R}^{2}\right)$, Quadrado Médio do Erro (QME), bem como pela análise de gráficos, plotando a predição da rede versus a predição menos o real (resíduo). Com esta tese foi possível explicar os parâmetros de desempenho de matrizes pesadas, através da utilização de redes neurais artificiais. A técnica permite a tomada de decisões por parte do corpo técnico, baseadas em critérios objetivos obtidos cientificamente. Além disso, este método permite simulações das conseqüências de tais decisões e fornece a porcentagem de contribuição de cada variável no fenômeno em estudo.

Descritores: avicultura, gerenciamento, reprodutoras pesadas, redes neurais artificiais, inteligência artificial.

\footnotetext{
* Tese de Doutorado n.6 (Especialidade: Sanidade Avícola). 116f. Programa de Pós-Graduação em Ciências Veterinárias da Faculdade de Veterinária, Porto Alegre - UFRGS. CORRESPONDÊNCIA: A.S. Guahyba [e-mail: adriano@guahyba.vet.br].
} 


\title{
USE OF ARTIFICIAL INTELLIGENCE(ARTIFICIAL NEURAL NETWORKS) IN THE BROILER BREEDERS MANAGEMENT**
}

\author{
ADRIANO DA SILVA GUAHYBA \\ Carlos Tadeu Pippi Salle (Adviser - UFRGS) \\ Vera Beatriz Wald (Co-Adviser - UFRGS)
}

Committee:

Alberto Back MERCOLAB

Antônio Mario Penz Júnior UFRGS

Ari Bernardes da Silva UFRGS

An economic activity with the magnitude of the poultry industry, which uses top line equipment and services, generally is lead to make decisions involving all production parameters, based in subjective criteria. The aim of this paper is to study the use of artificial neural networks to estimate performance parameters in broiler breeders, belonging to a South Brazilian poultry farm. Data from 11 breeding flocks was recorded between $9^{\text {th }}$ of November, 1997 and $10^{\text {th }}$ of January, 1999 and from 21 broiler production breeder flocks, between $26^{\text {th }}$ of April, 1998 and $19^{\text {th }}$ of December, 1999. The data used corresponds to 273 data lines from the breeding phase and 689 data lines from the production phase, obtained from weekly recordings. Artificial neural networks processed these datas. The artificial neural network models that were generated were compared and selected based on its determination coefficient $\left(\mathrm{R}^{2}\right)$, Mean Squared Error (MSE), and by graphical analysis of the plot of network predictions versus the predictions minus the actual data (residue). The authors conclude that it is possible to explain the performance parameters of broiler breeders, with the use of artificial neural networks. The method allows the decision making by the technical staff to be based on objective criteria, obtained scientifically. Besides that, this method allows simulation of the consequences of these decisions, and estimates the contribution of each variable used in the phenomenon under study.

Key words: poultry, management, broiler breeders, artificial neural networks, artificial intelligence.

Presented: 19 november 2001

** Doctoral Dissertation no.6 (Field: Avian Pathology). 116p. Postgraduate Program in Veterinary Sciences, Faculty of Veterinary Medicine, Porto Alegre - Federal University of Rio Grande do Sul (UFRGS)/Brazil. CORRESPONDENCE: A.S. Guahyba [e-mail: adriano@guahyba.vet.br]. 